Kennedy, G. C. (1957). F. Endocr. I6, 9.

Kennedy, G. C. (1967). In Handbook of Physiology. Alimentary Canal. Sect. 6, Vol. 1, p. 337 [C. .F Code, editor]. Washington, D.C.: American Physiological Society.

McCance, R. A. \& Widdowson, E. M. (1964). In Mammalian Protein Metabolism, Vol. II. p. 225. [H. N. Munro and J. B. Allison, editors]. New York: Academic Press.

Mannets, M. J. \& McCrea, M. R. (I963). Br. F. Nutr. I7, 495.

Mayer, J. (1953). New Engl. F. Med. 249, 13.

Snyderman, S. E. \& Holt, L. E. Jr. (I96I). F. Pediat. 58, 237.

Widdowson, E. M. (1947). Spec. Rep. Ser. med. Res. Coun. no. 257. London: H.M. Stationery Office.

Widdowson, E. M. (1950). Nature, Lond. 166, 626.

Widdowson, E. M. \& McCance, R. A. (1960). Proc. R. Soc. B. 152, 188.

Widdowson, E. M. \& Spray, C. M. (195 I), Archs Dis. Childh. 26, 205.

\title{
Physiological changes affecting voluntary food intake in ruminants
}

By J. M. Forbes, Department of Agricultural Sciences, University of Leeds, Leeds $L S 29 \mathscr{J} T$

Although the basic control of voluntary food intake in ruminants is imperfectly understood, it has been possible to study and describe the response in food intake to various changes in the environment (especially the diet) and within the animal. This paper deals with the effects within animals of physiological changes on voluntary intake. There have been many observations made on the effects of growth, development, reproduction and pregnancy on intake and, recently, some experimental work has begun to explain these observations.

The literature on the effects of pregnancy and lactation on voluntary intake has been reviewed (Forbes, 1970a) and this paper will attempt to correlate the results of some recent experiments with the more general framework of ideas which has been put forward elsewhere.

\section{The early post-weaning period}

Even when unlimited amounts of milk are offered to young calves and lambs, they begin to chew solid food at about 2 weeks of age and crave for it if it is not available. Under natural conditions, weaning is slow and the transition to solid food intake is prolonged and may not be complete until 6 months of age. Under modern husbandry conditions, calves are weaned at about 4 weeks old, at a time when their solid food intake is still very low. The withdrawal of milk does, however, rapidly stimulate the intake of solids (e.g. Hodgson, 1971a).

Diets with a high concentration of metabolizable energy are usually offered during and after weaning. It is unlikely that rumen capacity limits voluntary intake of such diets immediately after weaning because feeding fibrous materials at this time results in a greater volume of rumen contents (Hodgson, $197 \mathrm{I} b$ ).

To study the importance of rumen fill in limiting the voluntary food intake of growing calves, Hodgson ( $197 \mathrm{Ic}$ ) added food to, or removed digesta from, the rumens of fistulated calves. Fig. I shows the change in intake of the two diets 30 (2) 3 
which were induced by altering the amount of digesta in the rumen immediately before the meal. Two weeks after weaning, when the calves were 7 weeks old, there was no significant effect on voluntary intake. As they aged to 13 weeks there was a significant increase in response and in several instances when food was added to the rumen there was over-compensation in the calves' reduction in food intake, which was attributed to the use of wetted food, rather than rumen digesta, for the rumen additions.

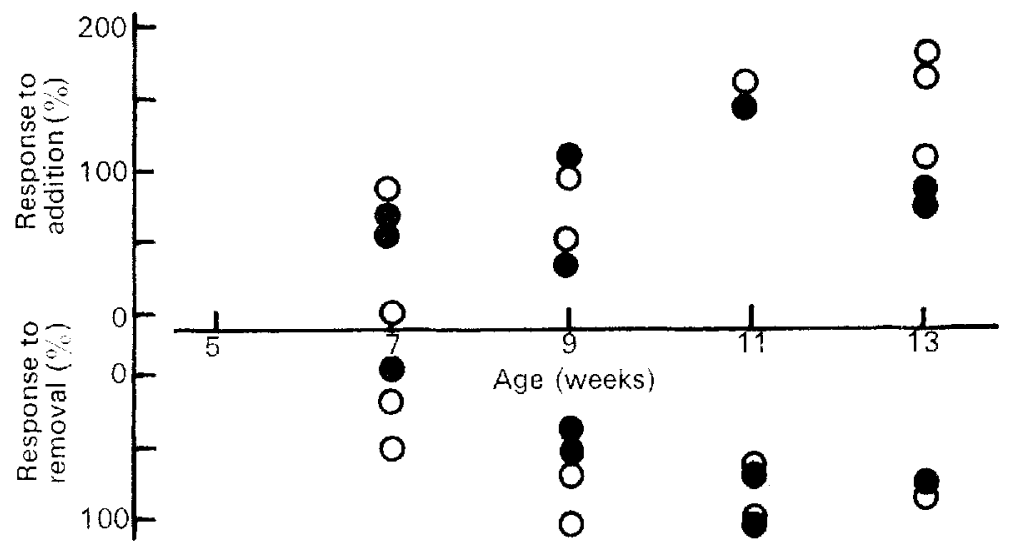

Fig. 1. Changes in voluntary dry-matter intake by calves in response to addition of food to, or removal of digesta from, the rumen via a fistula, expressed as percentages of dry matter added or removed. $\bigcirc$, chopped, dried grass; $\bullet$, ground, pelleted, dried grass. (Hodgson, I 97 I $c$.)

These results suggest that as solid food intake developed there was an increase in the importance of rumen distension which reached its 'adult' role at about I I weeks of age. The size of the rumen, relative to body-weight, also reached adult proportions at about this age. During the period of transition, increases in food intake were achieved by an increase in the time per day spent eating. Arrival at the 'adult' pattern was characterized by a stable rumen volume and any further increase in intake depended on an increase in the rate of eating but not in total time spent eating. With calves, this change occurred when solid food intake had reached $1 \cdot 5$ $\mathrm{kg}$ dry matter per d (Hodgson, I968), which was approximately the same as the level of voluntary intake at I I weeks of age when calves had attained the ability to compensate fully for addition to, or removal from, the rumen. By this time, therefore, calves appear to have fully developed ruminant characteristics which are not present at weaning.

The solid food intake of the newly-weaned calf is probably limited neither by physical nor metabolic control mechanisms, but probably by palatability factors. Adding sugar to a concentrate diet stimulated its intake by young calves yet had no lasting effect on its intake by grown heifers (Kare, I959).

\section{Growth to maturity}

Although voluntary food intake increases as the animal grows, it does not do so in direct proportion to the increase in body-weight. When intake was expressed as 
a proportion of live weight (Fig. 2) there was a decline from $25 \mathrm{~g}$ dry matter per $\mathrm{kg}$ live weight per d at $225 \mathrm{~kg}$ to $\mathrm{I} 7 \mathrm{~g}$ dry matter at $425 \mathrm{~kg}$ in Friesian cattle fed on a cubed diet in England (Pickard, Swan \& Lamming, I969) and in Herefords offered a similar diet in Kenya (Rogerson, Ledger \& Freeman, r968). Introducing older animals to the same diet (Pickard et al. 1969 ) resulted in a higher level of intake per unit of body-weight and this seems to be the main factor involved in compensatory growth (Bassett, 1960 ).

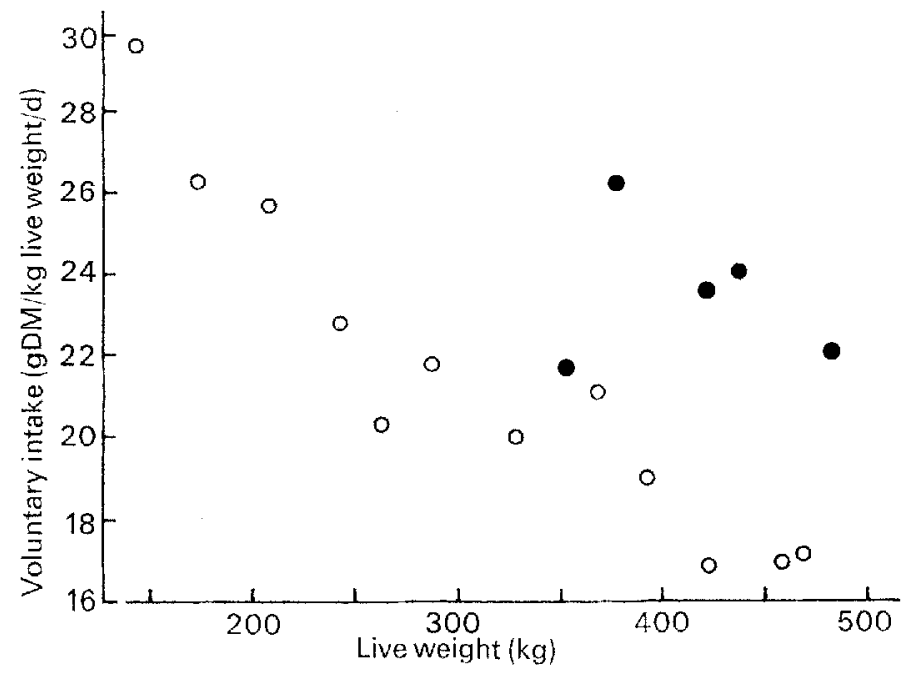

Fig. 2. Voluntary intake of a pelleted concentrate diet by growing cattle. $O, 150 \mathrm{~kg}$ live weight at start of trial; , $300 \mathrm{~kg}$ at start. (Pickard et al. 1969). Dм, dry matter.

In these experiments, voluntary intake was related linearly to live weight $t^{0.58}$ (calculated from the results presented by Pickard et al. 1969) and live weight 0.5 (Rogerson et al. 1968). With grazing calves, heifers and cows, Hodgson \& Wilkinson (1967) found the exponent to be $0.6 \mathrm{r}$ and with young grazing cattle, Holmes, Jones \& Drake-Brockman (1961) calculated 0.62 to be the best exponent for body-weight. Both Blaxter (1960) and Brierem (1960) expressed the view that for growing ruminants, voluntary intake increases with live weight ${ }^{0.6}$ rather than with live weight $t^{0.73}$ which is generally found to be so when comparing adult animals. This apparent anomaly is partly explained by the results of Brody (1945) which show that the resting metabolic rate of growing cattle increases with live weight ${ }^{0.6}$ at weights above $150 \mathrm{~kg}$.

The use of 0.73 (or $0.66,0.7,0.75$ ) as an exponent for live weight is therefore not justified when comparing food intakes of growing animals of the same species.

The effects on intake of abdominal fat which is deposited as an animal approaches maturity have been dealt with in an earlier contribution to this meeting (Bines, 1971).

\section{Oestrus cycle}

It has been noted that the voluntary food intake of ewes sometimes declines during oestrus (Tarttelin, 1968), probably because of the raised plasma oestrogen 
level at that time. Forbes \& Rook (1970) infused oestradiol into lactating goats and found that the resultant depression in food intake was greatest when the goats were in oestrus.

\section{Pregnancy}

Although there is sometimes a small increase in food intake in mid-pregnancy in sheep (see Forbes, I970a), the situation in cattle is normally confused by lactation. The very large increase in voluntary intake which is caused by increased progesterone secretion in pregnant non-ruminants carrying large litters does not appear to occur in sheep or cattle. This may be partly due to the smaller number of foetuses normally carried by ruminants, but may also be due to the ruminant's lack of positive response to progesterone. A search of the literature reveals no instance in which progesterone treatment has stimulated voluntary food intake in ruminants. However, the efficiency of utilization of nutrients is increased by pregnancy (Brockway, McDonald \& Pullar, 1963) and sometimes during progestin treatment (O'Brien, Bloss \& Nicks, 1968).

The increase in intake in mid-pregnancy might be caused direct by the increase in metabolic rate which has been shown to occur (Brockway et al. 1963) and the effect on intake of an increased drain of nutrients from a fed to a hungry sheep using an 'artificial placenta' is now being investigated (Forbes, 1971).

In the last few weeks of pregnancy there is often a significant decline in voluntary intake (see Forbes, 1970a). There are several possible explanations for this decline.

(a) Physical compression of the digestive tract. By cross-sectioning sheep slaughtered at different stages of pregnancy, Forbes (1968) has shown that the rumen is compressed by the uterus in the last 5 weeks before parturition and the decline in volume of rumen contents has been related to the decline in food intake (Forbes, 1969a). Fig. 3 shows that, as the volume of the uterus plus abdominal fat and other 'incompressible' abdominal contents increased, the volume of rumen contents decreased and that voluntary intake of hay was positively related to rumen volume. It could be argued that a reduction in intake caused by some other factor (see below) would lead automatically to a reduction in the volume of rumen contents. Under those circumstances, however, one would anticipate a deceleration in rate of passage of undigested particles through the digestive tract whereas the observed effect of pregnancy is to accelerate rate of passage in sheep (Graham \& Williams, I 962; Forbes, I970b). It is likely that compression of the rumen limits food intake in late pregnancy, particularly with fat animals fed on roughage diets.

(b) Endocrine changes. The intake of concentrated diets is thought to be limited metabolically rather than by the physical capacity of the digestive tract. There have been several instances where the voluntary intake of concentrates by cattle (Aitken \& Preston, 1964; Owen, Miller \& Bridge, 1968) and sheep (Forbes, 1970b) has decreased in late pregnancy, a phenomenon which cannot reasonably be accounted for by compression of the rumen. As mentioned above, oestrogen depresses food intake and a progressive increase in oestrogen secretion occurs during the second half of pregnancy in ruminants. In cows, there is an approximately 
Vol. 30

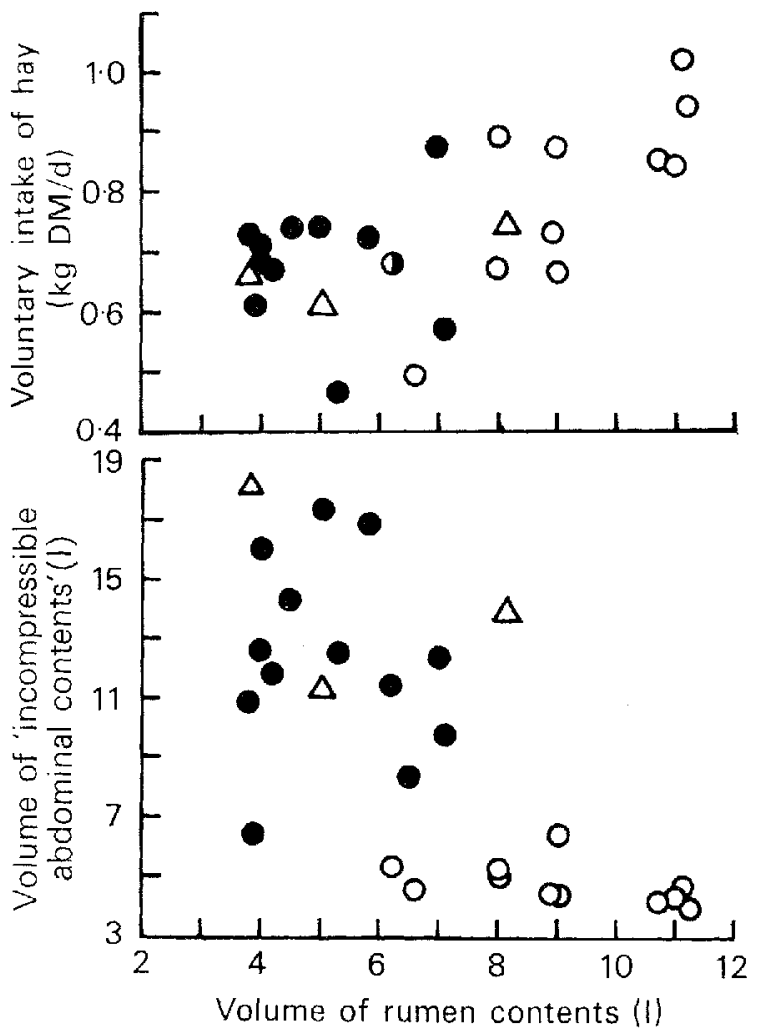

Fig. 3. Relationships in ewes between voluntary intake of hay before slaughter and volume of 'incompressible abdominal contents' (uterus, fat, kidneys, empty digestive organs, spleen, liver) and volume of rumen contents at slaughter. $O$, non-pregnant ewes; e, pregnant ewes carrying a single foetus; A, carrying twin foetuses. DM, dry matter.

(a)

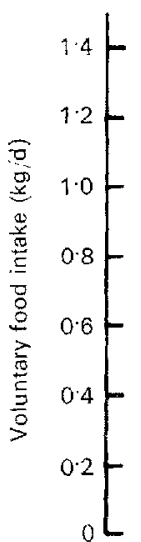

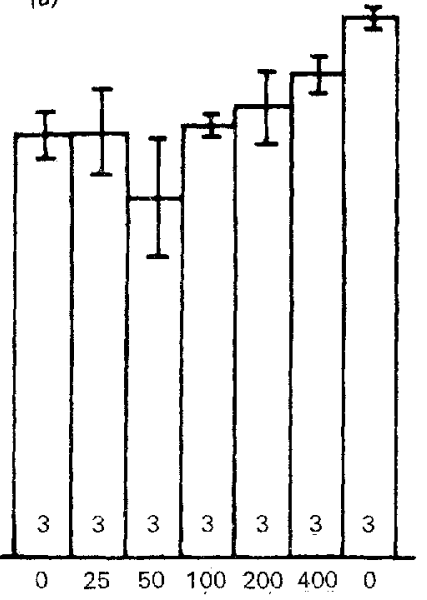

(b)

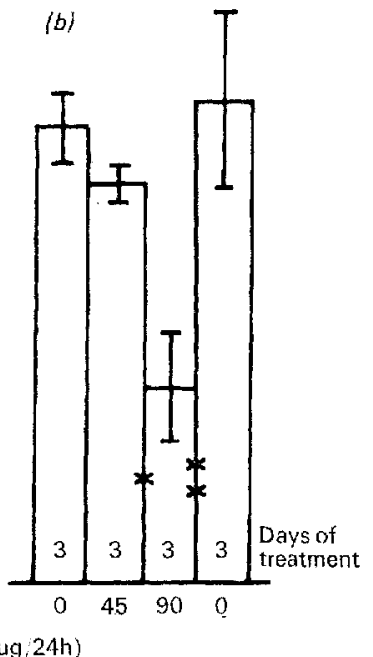

Fig. 4. Examples of the effects of intravenous infusions of oestradiol on voluntary intake of $a$, hay and $b$, concentrates by wether shecp. The vertical bars indicate the standard errors, $* P<0.05 ; * * P<0.0$. 
tenfold increase in urinary excretion of oestrogen metabolites as pregnancy progresses (Hunter, Erb, Randel, Garverick, Callahan \& Harrington, 1970). Assuming that a similar increase occurs in the ewe and that the production rate of oestradiol is $5 \mu \mathrm{g}$ per $24 \mathrm{~h}$ in the non-pregnant ewe (Short, McDonald \& Rowson, r963), one would expect a production rate in late pregnancy equivalent to $50 \mu \mathrm{g}$ oestradiol per $24 \mathrm{~h}$.

The effect of intravenous infusions of oestradiol on the voluntary intake of hay or concentrates by wether sheep has been studied (Forbes, unpublished observations). Fig. 4 shows typical results: there was no consistent effect on hay intake, even at high levels of infusion; with the concentrate diet, on the other hand, intake was consistently depressed by infusions containing quantities of oestrogen similar to those secreted in late pregnancy. This provides a possible explanation for the observed decline in concentrate intake by cattle and sheep in late pregnancy.

(c) Protein deficiency. It has been suggested that the low intake of diets with crude protein contents of less than $4 \%$ might be caused by an inhibition of metabolism due to lack of amino acids (Egan, 1965). With the increased amino acid requirements of late pregnancy it might be expected that the dietary crude protein content below which intake is limited by this means might be raised. However, the efficiency of retention of dietary nitrogen increases with advancing pregnancy and the amount of dietary nitrogen necessary to achieve a nitrogen retention of zero actually declines during pregnancy (Robinson \& Forbes, 1967). It is, therefore, unlikely that lack of protein would impose a limitation on the intake of the feeds normally offered to pregnant ruminants in Britain.

(d) Heat production. This increases by up to $50 \%$ by the last week of pregnancy in ewes (Brockway et al. I963) and might depress intake according to the thermostatic theory. Much greater increases in heat production occur in lactation, at a time of year when environmental temperatures are usually higher than during pregnancy, yet voluntary intake is invariably higher after parturition than before (see Forbes, I970a). Thus, there is no reason to believe that the decrease in food intake in late pregnancy is caused by heat stress.

The most likely reasons so far proposed for low voluntary intake in late pregnancy are, therefore, physical and endocrinological. It is paradoxical that supplementation of a basic roughage diet with concentrates in late pregnancy seems to ensure maintenance of an adequate level of nutrient intake.

\section{Lactation}

Although food intake always increases after parturition, it does not reach a peak until about the 6th week of lactation in cattle, or slightly earlier in sheep. The expulsion of the foetus immediately gives ample room for expansion of the rumen, so that the relatively slow development of the increase in intake is presumably not dependent on a slow increase in digestive capacity. Treacher (1970) fed pregnant ewes at three levels of nutrition and then offered ground, pelleted dried grass ad lib. during lactation. The high-plane ewes, which presumably had greater quantities of abdominal fat, had the highest level of food intake in lactation. They were, however, 
giving a greater yield of milk than the medium- or low-plane ewes and their higher intake was probably stimulated by their greater nutrient requirements, i.e. metabolic control. When chopped hay was fed to lactating ewes (Hadjipieris \& Holmes, I966; Treacher, 1967) the increase in intake following parturition developed more slowly than in similar ewes which were fed on ground, pelleted dried grass. This suggests that with long roughages intake is limited physically even at the peak of lactation, an idea supported by the results of Forbes $(1969 b)$ from ewes fed on hay.

In view of the practical importance of milk yield in ruminants and the widely observed correlation between yield and voluntary food intake (see Forbes, r970a), we need to know more about the factors which limit the food intake of lactating ruminants under different circumstances.

\section{Conclusion}

Recent work has shown how some of the changes in the voluntary food intake of growing, pregnant and lactating ruminants are related to physical, metabolic and endocrine changes within the animal. A further explanation of these effects should be possible when the basic control mechanisms of food intake in physiologically stable ruminants are more fully understood.

\section{REFERENCES}

Aitken, J. N. \& Preston, T. R. (1964). Anim. Prod. 6, 260.

Bassett, J. M. (I 960 ). The influence of maintenance feeding and subsequent compensatory effects on the pattern of growth and development in lambs. $\mathrm{PhD}$ Thesis, University of Reading.

Bines, J. (1971). Proc. Nutr. Soc. 30, x I6.

Blaxter, K. L. (Ig6o). Proc, int. Grassld Congr. virr, Reading, In Discussion p. 490.

Brierem, K. (1960). Proc. int. Grassld Congr. vur. Reading, In Discussion p. 490.

Brockway, J. M., McDonald, J. D. \& Pullar, J. D. (1963). F. Physiol, Lond, 167, 3 18.

Brody, S. (1945). Bioenergetics and Growth. New York: Reinhold.

Egan, A. R. (1965). Aust. F. agric. Res. 16, 473.

Forbes, J. M. (1968). F, agric. Sci., Camb. 70, 171 .

Forbes, J. M. (1969a). F. agric. Sci., Camb. 72, I 19.

Forbes, J. M. (1969b). Anim. Prod. r1, 263.

Forbes, J. M. (1970a). Br. vet. 7. 126, I.

Forbes, J. M. (1970b). J. Anim. Sci. 31, 1222.

Forbes, J. M. (r971). Proc. Nutr. Soc. 30, $22 \mathrm{~A}$.

Forbes, J. M. \& Rook, J. A. F. (1970). F. Physiol., Land. 207, 79 P.

Graham, N. McC. \& Williams, A. J. (1962). Aust. F. agric. Res. 13, 894.

Hadjipieris, G. \& Holmes, W. (1966). 7. agric. Sci, Camb. 66, 217.

Hodgson, $J$. (1968). A study of some factors influencing the intake of solid food by young calves. PhD Thesis, University of Leeds.

Hodgson, J. (1971a). Anim. Prod. 13, 15.

Hodgson, J. (197 Ib). Anim. Prod. 13, 25.

Hodgson, J. ( ( 97 I $c$ ). Anim. Prod. (In the Press.)

Hodgson, J. \& Wilkinson, J. M. (1967). Anim. Prod. 9, 365.

Holmes, W., Jones, J. G. W. \& Drake-Brockman, R. M. (I96r). Anim. Prod. 3, 251.

Hunter, D. L., Erb, R. E., Randel, R. D., Garverick, H. A., Callahan, C. J. \& Harrington, R. B. (1970). 7. Anim. Sci. 30, 47 .

Kare, M. R. (1959). Proceedings of the Cornell Nutrition Conference for Feed Manufacturers p. $10_{3}$.

O'Brien, C. A., Bloss, R. E. \& Nicks, E. F. (1968). F. Anim. Sci. 27, 664.

Owen, J. B., Miller, E. L. \& Bridge, P. S. (1968). F. agric. Sci., Camb. 70, 223.

Pickard, D. W., Swan, H. \& Lamming, G. E. (I969). Anim. Prod. r1, 543.

Robinson, J. J. \& Forbes, T. J. (1967). Br. J. Nutr. 21, 879.

Rogerson, A., Ledger, H. P. \& Freeman, G. H. (1 968). Anim. Prod. ro, 373.

Short, R. V., McDonald, M. F. \& Rowson, L. E. A. (1963). F. Endocr. 26, 155. 
Tarttelin, M. F. (1968). F. Physiol., Lond. r95, $29 \mathrm{P}$.

Treacher, T. T. (1967). Effects of nutrition on milk production in the ewe. PhD Thesis, University of Reading.

Treacher, T. T. (1970). Anim. Prod. 12, 23.

\title{
Behavioural factors in the regulation of food intake
}

\author{
By P. R. Wiepkema, Department of Zoology, State University, Groningen, The \\ Netherlands
}

\section{Introduction}

Mammalian food intake is a discontinuous process, in that feeding runs alternate with non-feeding intervals. These lifelong changes in overt behaviour indicate an underlying organization in which different needs alternately obtain priority. The way in which this channelling of needs might be realized can be investigated by analysing in detail how overt behaviour changes in time. It is of much importance to know how far food intake behaviour is influenced by the interaction processes involved.

Under $a d l i b$. conditions the frequency distribution of the duration of nonfeeding intervals suggests, at least in some species, the existence of meals (Le Magnen \& Tallon, I966; Thomas \& Mayer, I968; Wiepkema, I968). In these instances food intake depends on factors that determine frequency and size of meals. Probably these meal criteria are not caused by an identical set of causal factors. For instance, food deprivation may enlarge meal size without influencing the number of daily meals (Wiepkema, I968), whereas caloric dilution of the diet may have just the reverse effect (Le Magnen, 1969). The factors that determine exactly meal frequency will not be discussed here. They may be very difficult to unravel, since circadian processes also contribute to the distribution of meals during a $24 \mathrm{~h}$ period (Le Magnen \& Devos, 1970).

\section{Meal size}

Meal size depends on the caloric state of the animal and on sensory qualities (taste, volume, etc.) of the food (Le Magnen, I969; Thomas \& Mayer, I968). In addition, both groups of workers found a positive relationship between meal size and duration of the meal-to-meal interval immediately following. This indicates that the start of a meal depends on when calories stemming from the foregoing meal have been metabolized up to a critical level. No relationship was found between meal size and duration of the immediately preceding meal-to-meal interval. This suggests that meal size, being very variable, is independent of the caloric deficit incurred in its pre-meal period under normal ad lib. conditions. Meal size, or the end of a meal may be determined by quite other causes; one group of them, largely ignored in the literature, may be taken together as 'interaction processes between feeding and non-feeding behaviour'. The significance of such interactions will be 